\title{
Combating Resistance: The Case for a Global Antibiotics Treaty
}

\author{
Jonny Anomaly, Tulane University, Philosophy Department
}

Corresponding author: 105 Newcomb Hall, Tulane University, 1229 Broadway, New Orleans, LA 70118, USA. Tel.: (805) 2808443; Email: jonathan. anomaly@tulane.edu.

The use of antibiotics by one person can profoundly affect the welfare of other people. I will argue that efforts to combat antimicrobial resistance generate a global collective action problem that only a well-designed international treaty can overcome. I begin by describing the problem of resistance and outlining some market-friendly policy tools that participants in a global treaty could use to control the problem. I then defend the claim that these policies can achieve their aim while protecting individual liberty and state autonomy. Finally, I offer some suggestions for a treaty, drawing lessons from the failure of the Kyoto Protocol on climate change and the success of the Montreal Protocol on ozone depletion.

\section{Introduction}

As global trade, travel and population increase, microbes seize the opportunity to exploit new vectors and infect new hosts. We now share a microbial environment in the same way that we share an atmosphere. In both cases, people acting in one part of the world can affect the welfare of people in distant nations and future generations. Chlorofluorocarbons (CFCs) emitted in Alaska in the 1980s have contributed to an elevated risk of skin cancer among Australians born in the 1990s; carbon dioxide and methane gas emitted in Russia today contribute to an increased threat of death by parasitic infection in Micronesia in the next few decades. Similarly, antibioticresistant pathogens that evolve in Mexico (where antibiotics are virtually unregulated) can quickly find their way into European supermarkets and hospitals (where antibiotics are tightly regulated).

The argument for a global treaty to control antimicrobial resistance (AMR) rests on a pair of assumptions. The moral assumption is that we ought to prevent people in one country from acting in ways that cause significant harm to people in other countries, provided that the cost of preventing harm is sufficiently low. The economic assumption is that a global treaty regulating the production and consumption of antibiotics is the only way, or the only cost-effective way, of solving the free rider and assurance problems generated by collective efforts to curb the imprudent use of antibiotics. ${ }^{1}$

In order to motivate the rather strong moral claim that the current consumption of antibiotics creates harm significant enough to warrant global regulation, I begin with a brief primer on the nature and evolution of
AMR. I then use some familiar economic tools to explain our predicament, and consider how we might manipulate incentives to improve it. I conclude that using policy to manipulate incentives (which may impose additional costs on consumers) is consistent with the classical liberal conception of economic and social liberty. In the final two sections, I sketch some suggestions for a global treaty that strikes a balance between preserving the autonomy of each state and inducing the compliance of all states.

\section{The Evolution of Resistance}

Like many strategic interactions in the natural world, the relationship between hosts and microbes tends either to become symbiotic or antagonistic. ${ }^{2}$ When the relationship is antagonistic, what often follows is an evolutionary arms race in which hosts evolve new weapons to destroy pathogenic microbes and microbes evolve resistance to their host's arsenal. This is a predictable consequence of evolution by natural selection, and it has long occurred between microbes that parasitize one another (fungi and bacteria, bacteria and viruses, etc.), and between host organisms and the microbes that parasitize them.

The advent of antibiotics saved countless lives in the twentieth century, but it also escalated the arms race between parasitic bacteria and their hosts. Antibiotics usually work by entering a bacterium's cell wall and then either destroying it or disabling its ability to replicate. Bacteria exposed to antibiotics have evolved ingenious ways of protecting themselves. These include the 
development of a cell wall that blocks the penetration of deleterious chemicals, an efflux pump which bacteria use to selectively pump out chemicals that threaten their livelihood, and enzymes that disable antibiotics by degrading them into benign chemicals (Levy, 1998, 2002).

Antibiotic resistance can arise rapidly because of the unique ways in which bacteria can acquire genes. Bacteria generally contain plasmids-free floating circular strands of DNA that exist inside of the cell wall but outside of the chromosome-which confer the ability to express beneficial traits, including antibiotic resistance. Some bacteria carry thousands of plasmids and exchange entire plasmids (or plasmid cassettes) with other bacteria through conjugation. Like sex, conjugation allows for rapid evolution. Unlike sex, conjugation enables bacteria to exchange genes with members of different species. Bacteria can even acquire beneficial genes from dead bacteria and from bacteriophage viruses, which inadvertently extract DNA from one bacterium and insert it into another (Sachs, 2008; Levy, 1998). These methods of gene acquisition are commonly called horizontal gene transfer in order to distinguish them from the more familiar vertical transfer of genes from parent to child.

Once they emerge, genes that confer resistance to antibiotics can persist long after antibiotics have been removed from a bacterium's environment (Salyers and Amabile-Cuevas, 1997). This is because the cost of carrying genes that encode for antibiotic resistance is typically small, especially when the resistance genes are only expressed when antibiotics are present (Andersson and Levin, 1999). When genes are expressed only under certain conditions, they are much cheaper for an organism to retain since the only fitness cost they impose is the opportunity cost of replacing them with other genes that might be more immediately useful. This suggests that resistance genes will persist long after the removal of antibiotics (Andersson and Levin, 1999). Moreover, even when the cost of retaining resistance genes is significant, this does not imply that removing antibiotics will restore their efficacy by selecting against resistant strains. According to Salyers and Amabile, 'Although the incidence of resistant strains [of bacteria] may drop, it seldom falls to zero. This leaves a residuum of persistently resistant strains that can rebound rapidly to become the predominant strains if antibiotic use is resumed' (Salyers and Amabile, 1997, p. 2321).

The upshot of these two forces-horizontal gene transfer and the long persistence of resistance genes in the environment-is that the use of antibiotics by people in one region can significantly affect geographically and temporally distant people.

\section{Internalizing Externalities}

The primary forces driving the evolution of AMR are the overconsumption and misuse of antimicrobial agents. ${ }^{3}$ From an economic standpoint, the indictment of overconsumption is not like the value judgment made by those who accuse Americans of consuming too many pancakes. Rather, a resource is consumed 'too much' or 'too little' when its price fails to reflect its full private and social cost. Since the price of antibiotics currently does not include the significant costs that our consumption imposes on others, antibiotics are artificially cheap and consequently consumed more often and less prudently than they would be if their price reflected their full cost.

The external welfare affects, or externalities, of consumption can be positive or negative. In the case of antibiotics, taking an appropriate drug can generate positive effects on the user who is infected with a pathogen, and on the larger population who might otherwise have been infected by the user (Laxminarayan, 2007; Smith and Coast, 2004). When their use generates expected positive externalities without offsetting negative externalities, antibiotics are under-consumed (Selgelid, 2007). But these positive externalities are usually localized and ephemeral. In the long run, even the prudent use of antibiotics by many people tends to have a negative impact on others by decreasing the efficacy of antibiotics, and by selectively favoring microbes with AMR genes (Kades, 2005).

The artificially low price of antibiotics leads to several undesirable consequences. Firstly, since the benefits of using antibiotics go mainly to the user, while the costs are borne by all people with whom he shares a microbial environment, the risk of a patient's choice to consume (and a physician's choice to prescribe) antibiotics is effectively socialized. Assuming that the probability of contracting a resistant pathogen after a course of antibiotics is small, patients will often demand cheap antibiotics for infections that are either not bacterial or are bacterial but would clear up on their own with the help of a healthy immune system. Physicians will often accede to a patient's demand for antibiotics out of a fear of losing the patient's business, fear of litigation after misdiagnosis or because they lack the time or resources to accurately diagnose the patient (Laxminarayan, 2003).

A second consequence of the low cost of antibiotics is the increased opportunity cost of running diagnostic tests. When treatment is expensive, physicians respond by spending more time and money diagnosing patients in order to choose the most effective treatment. But when 
cheap antibiotics are widely available, there is less incentive for physicians to run costly tests to pinpoint which bacterium, if any, a patient is infected with, and consequently less incentive for pharmaceutical firms to develop more cost-effective diagnostic tests.

Finally, the low cost of many broad spectrum antibiotics leads to their controversial use as prophylactics in routine surgeries (Salyers and Amabile-Cuevas, 1997), their addition to soaps and cleaning products (Levy, 1998) and their widespread use as growth promoters in farm animals (Gorbach, 2001; Sachs, 2007; Anomaly, 2009).

When prices are distorted by externalities, as in the case of antibiotics, markets fail to yield an efficient allocation of resources in which buyer and seller are better off, and third parties are unaffected. Some take the current market failure for antibiotics to imply that we should socialize the distribution of antibiotics. According to Michael Selgelid, '[ $t$ ] he fact that the problem of drug resistance is global in scope ... is troubling. The case that globalization should include a global socialization of antimicrobials is, in any case, strengthened by reflection on the dynamics of drug resistance. We leave global provision of treatment for infectious diseases in the hands of profit-oriented commercial enterprise, patent incentives, and market mechanisms at our own peril' (Selgelid, 2007, p. 229).

Selgelid's solution is worth considering, but the existence of market failure should always be weighed against the risk of government failure, as well as the loss of liberty and efficiency that tend to follow from bureaucratic attempts to set prices and allocate resources. In many cases, market failures can be corrected with modest policy tools such as requiring manufacturers to disclose information, or manipulating the incentives buyers and sellers face by altering property rights or imposing corrective taxes and subsidies.

The market-based alternative to socialization, or command-and-control regulation, is to try to correct the market failure for antibiotics by bringing private and social costs into line, so that prices reflect the true cost of consuming antibiotics. The benefit of this approach is that it harnesses the power of prices to convey information to consumers. A high price tells us, in effect, 'don't consume this product unless other alternatives are likely to be ineffective or even more costly.' Three main marketbased mechanisms have been proposed to alter incentives that lead to the overconsumption of antibiotics: taxes and subsidies, changes to patent law and tradable permits for prescribing antibiotics.

Arthur Pigou was the first economist to argue that activities which generate negative externalities should be taxed in order to offset their social costs. It is important to recognize that Pigovian taxes are not 'sin' taxes. Pigovian taxes are supposed to discourage actions that impose welfare losses on other people; sin taxes are intended to discourage what some regard as self-destructive behavior by making it prohibitively expensive. Because sin taxes use state power to regulate self-regarding behavior, they are inimical to classical liberalism. Pigovian taxes, by contrast, are much more palatable to liberals since they aim to discourage socially harmful behavior rather than self-destructive behavior.

According to Pigou, the function of the current petrol tax in England is to offset the cost of road deterioration and to control congestion and air pollution (1962, p. 193). Similarly, we might impose a tax on antibiotics-especially those most likely to be overused-in order to discourage socially harmful consumption (Rudholm, 2002). We could then use the revenue generated by the tax to compensate people infected with antibiotic resistant pathogens, or to fund research related to AMR. Pigovian subsidies, which are intended to encourage behavior likely to generate positive externalities, might be used to fund scientific research on the nature and spread of AMR, or to encourage the development of more cost-effective diagnostic technology, which would reduce the incentive to use broad spectrum antibiotics indiscriminately (WHO, 2001a; Kades, 2005). Such subsidies are less likely to be politically controversial if they come directly from revenue generated by Pigovian taxes. From a moral standpoint, we might say that they are not subsidies at all, but rather a form of indirect compensation to future people for the current use of a quasi-exhaustible resource, and the corresponding increase in resistance genes in the microbial gene pool that results from the overuse of antibiotics. ${ }^{4}$

The second market-based mechanism that might be used to decrease the socially harmful consumption of antibiotics is a cap-and-trade system. The basic idea is to cap the quantity of antibiotic prescriptions that hospitals or physicians are permitted to issue over a given quantity of time (with different caps for different classes of antibiotics). Physicians would then be forbidden from exceeding their budget, but permitted to buy the right to prescribe more from other physicians, while those using less than their budget would be permitted to sell their surplus prescriptions to other physicians or hospitals with a greater demand for antibiotics. The advantage of a system of tradable permits, according to Smith and Coast, is that 'Instead of setting the "price", and leaving the market to adjust the quantity, with permits the regulatory body sets the "quantity" and lets the price adjust in the market' (Smith and Coast, 1997, p. 20). Smith and Coast argue 
that the information needed to establish an optimal, or at least acceptable, quantity of permits to allocate would be easier to obtain than the information needed to establish and adjust a Pigovian tax.

Patents are a third way of correcting price distortions that lead to the overuse of antibiotics. Patents essentially grant firms a temporary monopoly on a product, which allows them to charge higher prices than they could if they were forced to share their discovery. These higher prices discourage the low value use of antibiotics, and also encourage firms to develop new drugs and diagnostic technology so that they too can enjoy temporary monopoly profits.

Unlike Pigovian taxes and tradable permits, patents already exist, but don't seem to be working optimally. ${ }^{5}$ One reason may be that the research and development of new antibiotics can take decades, so that relatively short-lived monopolies fail to provide enough incentive to conduct costly campaigns to develop new drugs. This suggests that we may need to extend patents, and perhaps increase funding for basic science research surrounding AMR. ${ }^{6}$ The practical advantage of patents over direct government involvement in the research and development of new drugs is that patents give investors monetary incentives-incentives which bureaucrats typically lack-to carefully choose which research seems most promising.

Nevertheless, all three market-based ways of discouraging the overuse of antibiotics face problems. For example, in order to establish an optimal tax rate, patent length or quantity of tradable permits, government planners would need to rely on research from scientists who are shielded from political pressure. Even if this could be achieved, tradable permits raise special problems by giving physicians perverse incentives. For example, tradable permits might encourage financially troubled physicians or hospitals to withhold prescriptions to needy patients so that they could sell permits to other hospitals in order to raise revenue.

A permit system could also bring premature death and disease to those who enter a hospital that has already exceeded both its antibiotic budget and its capacity to buy permits.

Patents could potentially create the opposite problem: extending the length of patents on antibiotics might increase the supply of drugs without decreasing demand. This is true because although in the short run patents raise the price of a patented drug, in the long run, patents may lower the average price for off-patent drugs, and thus raise aggregate consumption. For these reasons, Pigovian taxes may be preferable to patent adjustments or tradable permits.
Regardless of which mechanisms are chosen, a nation's policies cannot fully insulate its citizens from being harmed by the consumption choices of people in other nations. Since the externalities of using antimicrobial drugs are potentially global, the preservation of antimicrobial efficacy and the production of new information and technology associated with the diagnosis and treatment of microbial infections are global public goods (Sandler, 1997; Smith and Coast, 2004). Identifying an outcome as a global public good does not imply that provision of the good requires the cooperation of all nations, or even that its provision is worth encouraging. Public goods provide, at best, a prima facie case for government action.

Although some public goods should be supplied by the state, or by an alliance of states, the function of a government guided by liberal principles is not to optimize utility by supplying public goods whenever the expected social benefits exceed the collective costs to individuals. This is partly because some public goods can be efficiently supplied through private contracts, and because most public goods are impure- that is, they do not benefit everyone, or benefit everyone equally. Thus, before I discuss why we need a state-sponsored global antibiotics treaty, I will briefly defend the view that mechanisms like those discussed above, which force consumers to internalize the negative externalities of using antibiotics, are consistent with the classical liberal view of the state.

\section{The Harm Principle}

Liberalism as a moral basis for justifying the use of political power reflects the idea that individual liberty should be considered the moral default, and that the use of coercion to curtail liberty stands in need of justification (Gaus, 1999). The liberal commitment to economic and social freedom was most famously formulated by John Stuart Mill: 'the only purpose for which power can be rightly exercised over any member of a civilized community, against his will, is to prevent harm to others' (Mill, 2002, p. 11). On this view, harm to others is a necessary but not sufficient condition for justifying government interference with liberty.

Free markets are often said to be justified because leaving people free to engage in voluntary exchange is intrinsically good (liberalism), and because free trade tends to promote social wealth (utilitarianism). The main exceptions occur when one or both parties possess unreliable information about the products exchanged, and when the transaction between willing buyer and seller imposes uncompensated harms on third parties. 
From the standpoint of liberalism, the existence of harmful third party effects does not necessarily warrant government intervention. For example, suppose that you sell me the last taco from your taco truck, so that I am happy with my lunch and you are happy with the cash I paid for it. Suppose next that the person at the back of the line desperately wanted a taco for lunch. The case could be made that we have harmed him by frustrating his desire for a taco.

This example illustrates two points. Firstly, not all harms, or welfare losses, are morally significant. There is no moral parity between your inability to purchase a taco at this particular time and place because I bought the last one, and your inability to breathe because I choked you to death in order to get the last taco. Thus, not all harms generate legitimate claims for compensation or remediation (Feinberg, 1987; Gaus, 1999; Anomaly, 2009).

Secondly, some harms are so trivial that they can be internalized at little cost and without significant welfare losses by those involved. If I am indifferent between a taco and a burrito, or have only a slight preference for a taco over a burrito, we might agree to a voluntary exchange that leaves all of us reasonably happy. More generally, if the transaction costs associated with bargaining are low, and if the externalities of an exchange are trivial and localized, we might wish to leave the parties free to negotiate a private solution in order to avoid unnecessary government intrusion (Coase, 1960).

However, the harms imposed by the use of antibiotics are nothing like this. Firstly, the harmful effects of AMR are potentially large, and the microscopic parasites that produce these effects are largely invisible. Secondly, the costs of one person's choice to use antibiotics are not only diffuse, but essentially unpredictable, in part because of the role randomness plays in the evolution and dispersion of genes that confer resistance. ${ }^{7}$ Thirdly, the victims of resistant microbes and those whose choices led to their existence are generally scattered across the globe and across time, and are therefore difficult to identify. Finally, for all of the reasons mentioned above, the transaction costs associated with bargaining between infected people and those who infect them are prohibitively high. Thus, liberals should agree that government intervention may be desirable to force consumers to internalize the negative effects of their use of antibiotics in order to prevent harm to third parties.

Although there is no precise formula for assessing whether a potentially harmful activity should be regulated, there are a number of factors that seem relevant (Gaus, 1999). Firstly, we should consider whether compensation is likely to be paid to those who bear the costs of a harmful activity. Secondly, we should consider the like- lihood, severity and distribution of harm that result from an activity. Thirdly, we should ask ourselves whether the compensating benefits of permitting the activity outweigh the harm of permitting the activity.

In the case of antibiotics, the likelihood, severity and distribution of harm in the form of AMR are a function of the patterns of use. It is clear that those who benefit from cheap antibiotics are sometimes the same class of people as those who end up contracting resistant microbes, but this is certainly not always the case. It is also clear that although one person's choice to take a course of antibiotics (or to take a course without completing it) typically imposes only a trivial risk of harm on others, the collective use of antibiotics imposes grave risks of harm on people around the globe. This suggests that some sort of state action to regulate antibiotic use can be justified on liberal grounds.

The only catch is that Mill's version of the Harm Principle focuses more on harms created by a particular person's actions than on harms that depend on the independent actions of many people. To highlight the difference, it may be helpful to think of drug resistant microbes as a kind of DNA pollution emitted in a common environment (Sachs, 2008). The risks imposed by DNA pollution are analogous to those imposed by certain kinds of air pollution. Some chemicals are not toxic below a certain threshold. Others are toxic in small amounts, but produce elevated risks and severity of harm as they accumulate in the atmosphere. Likewise, it seems clear that a few people creating DNA pollution do not impose significant risks on many people, but that the risks imposed by DNA pollution are partly a function of the quantity of antibiotics used, and the way in which they are used. Thus, in order to justify some form of government regulation of antibiotics, we need a harm principle that applies to cases in which the extent, severity and probability of harm increases as the number of users of antibiotics increases.

One such proposal is the Public Harm Principle, formulated by Gerald Gaus as follows:

If an accumulation of $\mathrm{X}$ actions causes a serious setback to welfare interests, and if the harm is serious enough that it merits limiting one person's liberty, then everyone's liberty should be similarly limited (Gaus, 1999, p. 196).

This principle essentially combines Mill's Harm Principle with a principle of fairness, which holds that if our combined actions substantially elevate the risk of harm to others, then if any of us should bear the costs, all of us should bear the costs. In the case of antibiotics regulation, since all users are responsible for the harms 
imposed by antibiotics, fairness demands that we pay the social costs in proportion to our use. One way to do this, I have suggested, is to try to make the price of taking antibiotics reflect the full social costs generated by our consumption.

It may be objected that regulating antibiotics in this way will increase the price of drugs, which will have a disproportionate impact on people who have less income to spend on health care. This is a legitimate concern, and some may respond by advocating state-financed provision of some antibiotics for the poor either as a matter of justice (because they deserve equal basic health provision) or as a matter of prudence (because we all suffer greater risks when the poor underuse or misuse antibiotics). But the general response to this objection is that nobody has the right - not even the poor- to inflict uncompensated harms on other people against their will. Thus, although there is a strong case for state-financed support of eradication campaigns, and for those who might be tempted to quit a costly course of antibiotics once it is started (since such people put everyone at risk), there is no obligation for states to make antibiotics as cheap and available as they are today. The main obligation is rather to make antibiotics expensive enough to curb low value consumption and encourage the development of new treatments in order to protect innocent parties.

\section{Collective Action and State} Autonomy

Although liberalism is primarily a doctrine about the obligation of states to respect the free choices of their citizens, many liberals also support the autonomy of states in the international sphere. The reason seems to be that democratic states, at least, are generally more responsive to the interests of their citizens, and that citizens should not be held accountable to a global government over which they lack control. The problem, on this view, is how to handle cases in which the welfare of the citizens of different states is deeply intertwined-in particular, cases in which people in on one nation act in ways that harm people in other nations. An obvious alternative to ceding power to a world government to set and enforce mutually beneficial rules is to allow independent nations to forge treaties. ${ }^{8}$ Indeed, international law already recognizes state autonomy by granting nations the freedom to decide whether or not to participate in treaties (Barrett, 2007, p. 93).

Although all nations would benefit from a global reduction in the imprudent use of antimicrobial drugs, the incentives nations face differ. In the international sphere, incentives to free ride on the cooperative efforts of other nations depend in large part on the extent to which the citizens of a particular country bear both the costs and benefits of their actions. For example, in the case of greenhouse gas emissions, a tiny island nation like Tuvalu will never bear the costs of its own emissions, since they are widely dispersed and have no real impact on climate change. The leaders of Tuvalu face strong incentives to free ride on global efforts to cutback greenhouse gas emissions. In contrast, when it comes to infectious disease, the geographically isolated residents of Tuvalu could bear severe costs of permissive policies that foster the evolution and spread of drug-resistant microbes.

This example illustrates two crucial factors that determine a nation's incentives to cooperate with other nations to produce outcomes from which all nations benefit. The first is how the costs and benefits of a set of actions are distributed. When a significant portion of the costs and benefits of a collectively harmful activity are borne by the same nation, and the costs exceed the benefits, that nation has a unilateral reason to use its coercive power to change the behavior of its citizens. When the costs of a harmful activity are dispersed across the globe, but the offsetting benefits of permitting that activity are concentrated within a nation's boundaries (for example, the financial benefits to Tuvaluans of using machinery that produces cheap energy but lots of greenhouse gas emissions), the nation's leaders have no incentive to compel its citizens to change their behavior.

A second factor that determines a nation's incentives to contribute to the provision of a global public good is how smooth or lumpy the production function for the good is. When a favorable outcome is produced incrementally, and the production of the outcome requires the effort of many people or nations acting independently, each prospective contributor-or small set of contributors, such as the population of Tuvalu-has powerful incentives to let others bear the cost of contribution, and to disguise their own lack of contribution. An effective global antibiotics treaty to control AMR must therefore structure incentives so that each nation finds cooperation attractive. It must also recognize that treaty participants are more likely to reveal true information about their use of antimicrobials when they believe they are benefiting from the treaty, and not being unfairly exploited by other beneficiaries.

What do incentives and self-interested reasons have to do with the moral claim that we should forge a treaty to control AMR in order to prevent some people from harming others? It is important to emphasize that when harms result from the cumulative impact of relatively 
benign actions, people face conflicting incentives in deciding how to act. When the harmful impact of our actions is small but visible (such as cutting in line), we can often rely on shame or social stigma to deter harmful actions; when the harm is invisible and diffuse, and when the probability that many other people will act in collectively harmful ways regardless of how you act is large, it is reasonable to conclude that we have a moral obligation to try to change the incentives people face, rather than merely trying to change their behavior through persuasion or social stigma. ${ }^{9}$ This is because in such cases people tend to reason prudentially rather than altruistically. ${ }^{10}$

This is not to say that we shouldn't try to persuade people to change their behavior-for example, to pollute less, to conserve water and to refrain from the gratuitous use of antimicrobial drugs. We may very well have a moral duty to do these things ourselves, and to persuade others to do the same. My contention is merely that in this and similar cases, using policy to manipulate the incentives people face is far more likely to reduce the existence of harm than relying on the conscience of independent actors. This is not merely a pragmatic concession; it is a claim about how best to apply liberal principles to a uniquely modern problem.

The remaining task is to give a sense of how an international treaty to control AMR can preserve individual liberty and state autonomy, while providing the leaders of each nation with incentives to ratify and comply with the treaty.

\section{Lessons from Montreal and Kyoto}

A lot can be learned from the Montreal Protocol on ozone depletion and the Kyoto Protocol on climate change. One of the main reasons Montreal has succeeded so dramatically in securing cooperation and compliance is its built-in flexibility. The Montreal Protocol stipulated that amendments could be made to the original treaty if at least two-thirds of its signatories supported them (Barrett, 2007, p. 77). This was extremely useful, since the relatively modest cuts in the use of ozone-depleting chemicals initially called for were not enough to protect people from sharp risks of contracting skin cancer, cataracts and other health problems associated with ozone depletion. The treaty was altered and the benefits are already being felt. ${ }^{11}$

Flexibility can also occur in the way in which a treaty permits its signatories to meet its demands. For example, one of the few successful provisions of Kyoto is that it places caps on the quantity of greenhouse gasses that nations are allowed to emit, but it permits each nation to decide whether to meet these caps with tradable permits, taxes or command and control mechanisms. Similarly, Eric Kades argues that 'an international accord to rationalize antibiotic use need not specify a single means of compliance; one nation might choose a Pigovian tax specified in the agreement, another might prefer long term patents. All that matters is that each nation limits key antibiotic usage to relatively serious cases' (Kades, 2005, p. 670).

In addition to being flexible, an effective treaty will distribute the burdens of compliance in a way that is perceived as fair and beneficial to all signatories. This is especially challenging because although AMR threatens people everywhere, the benefits of controlling AMR will be unevenly distributed. Iceland, for example, is a large country with a dispersed population and a climate that is not particularly attractive to people or microbes. Malaysia faces the reverse problem: its tropical climate and population density makes it especially susceptible to parasitic infections. This suggests that Malaysians may have a self-interested reason to comply with a costly treaty which Icelanders do not, and that Malaysians might be willing to bear more of the costs of ensuring that other countries comply than Icelanders would.

There is little doubt that a global treaty will raise the cost to consumers of antimicrobial drugs, especially in the short run. How much prices will increase will depend on the mechanisms a nation uses to force consumers to internalize the costs they currently impose on others. Assuming that devices like taxes, permits and patents will raise the costs of antimicrobial drugs for all people, how should the compliance costs imposed by a treaty be distributed between nations?

A natural suggestion for sharing the burdens of compliance is the benefit principle, which holds that a nation should contribute to a collective endeavor in proportion to its expected benefit (Sandler, 2004). This way of costsharing is superficially appealing because it recognizes that some nations will benefit more than others from a treaty, and would therefore be willing to pay more than others.

Nevertheless, there are two reasons to doubt that this principle for cost-sharing can work. Firstly, nations that are willing to pay more to ensure universal compliance with a treaty will have every incentive to strategically disguise their true preferences and argue that their expected benefits are lower than they actually are. Secondly, willingness to pay depends on ability to pay, so those nations that would be willing to pay more may not actually be able to support their preferences with money. In the case of AMR, it is plausible to suppose that many of the countries that would benefit most from universal compliance with a treaty-those nearest the equator, where 
infectious diseases are ubiquitous-are precisely those that can afford to pay the least.

This suggests that we must either reject the benefit principle as our standard of fairness or recognize that there may be a trade-off between our commitment to a fair treaty and our commitment to preventing harm by changing the incentives that prospective participants face. Recognizing this sort of trade-off between moral principles may seem like closet utilitarianism. But this is not necessarily so: it is possible not only to act on the basis of principles that are justified by non-utilitarian considerations but also recognize that the opportunity cost of satisfying one principle may be that another principle is not fully satisfied (Selgelid, 2009). It may be that our commitment to preventing harm and to (a certain conception of) the fair distribution of benefits and burdens requires this sort of trade-off. If so, a workable system of burden sharing must take account of the fact that universal compliance with a treaty will produce uneven benefits, and that since different nations have different abilities to pay for compliance, some states will have to sacrifice more than others, even if their relative gains are less. But we must also be careful not to abandon fairness, since it is likely that even if nations would benefit from implementing a treaty, if they think its terms are unfair, they are less likely to comply with it (Kaul et al. 1999, xxxii).

How do we encourage universal participation without abandoning fairness? The simple answer is to use the right combination of carrots and sticks. Precisely when it is best to use positive incentives rather than threats of punishment will depend on the case. But it is again instructive to compare the Montreal and Kyoto treaties.

The Kyoto Protocol called for the major industrialized nations of the world to cut their collective emissions by five per cent from 1990 levels, while it imposed no limits at all on the rest of the world. Thus, Kyoto offered no real incentives for participation by non-industrialized nations. This made the free-rider problem insurmountable, since very few (if any) nations feel the direct impact of their own greenhouse gas emissions.

Although many industrialized countries ratified Kyoto, most have failed to produce the cuts it requires, and crucial players such as the USA and Australia have completely withdrawn. It may be that American and Australian politicians withdrew from the treaty in order to shield themselves from voter disapproval over taking steps that might slow economic growth. But some have argued that regardless of the cost of implementing Kyoto, it would be unfair for industrialized countries to make large sacrifices, when other countries are exempt. Now that China is the biggest emitter of greenhouse gases, it seems especially naive to think that other nations would consider it fair to exempt nations such as China from bearing some of the cost of carbon reduction just because their per capita GDP remains relatively low.

In contrast to Kyoto, the Montreal Protocol contained several provisions to attract non-industrialized nations to sign on. Firstly, participants that lack the technological or financial ability to phase out their use of ozone depleting chemicals have been given a combination of cash subsidies, information about chemical substitutes and physical equipment that help them ease away from harmful CFCs. Secondly, in order to punish those unwilling to participate, Montreal imposes trade restrictions between treaty participants and non-participants in ozone depleting chemicals, as well as products that use such chemicals (such as refrigerators and air conditioners).

To be sure, trade sanctions are only effective when there are enough participants to severely diminish the markets available to non-participants. Those who crafted Montreal anticipated this problem by specifying that sanctions would not apply until a minimum number of nations had ratified the treaty (Barrett, 1999). Since Montreal gave immediate benefits even to poor nations for signing up, the critical mass was swiftly reached. In game-theoretic terms, Montreal's sanctions solved the free-rider problem posed by those who seek to benefit from a treaty without paying the costs, while its minimum participation clause solved the assurance problem faced by those who are willing to pay the costs but fear that others would not.

The biggest problem with mining Montreal for insights about burden sharing and incentives for participation is that while ozone depleting chemicals like CFCs can be substituted with only slightly more expensive alternatives, antimicrobial drugs do not admit of obvious or inexpensive substitutes. ${ }^{12}$

Nevertheless, given the grave risks posed by the global spread of AMR, it is clear that wealthier nations should be willing to pay more in order to bring other nations on board. For example, wealthier governments might wish to fund a global surveillance system to track the evolution and spread of outbreaks, or to purchase diagnostic technology from private firms and donate it to poorer countries (WHO, 2001b). ${ }^{13}$ They might also fund international efforts to train physicians and educate patients on the proper use of antimicrobial drugs. But these are relatively trivial costs. The big question is how to draw less affluent nations into a treaty that is likely to raise the cost of antimicrobial drugs for consumers and increase the cost of enforcing new laws for national governments. ${ }^{14}$

Although subsidies to poor nations are an obvious way of increasing their participation, if the goal is to forge a 
treaty that is both likely to be adopted and to protect the autonomy of independent states, the treaty should not require a massive transfer of resources from people in wealthier states to secure the compliance of poorer states. It should instead emphasize the losses that rogue states will incur to their own population by permitting the profligate use of antimicrobials, and by losing opportunities to trade with participating states. These mechanisms should help foster participation, preserve the autonomy of each state and, ultimately, decrease the threat of AMR to people in all states.

\section{Notes}

1. Although a robust treaty would cover all antimicrobials, I focus on antibiotics in order to simplify the discussion.

2. The technical terms for these relationships are mutualism (mutual benefit) and parasitism (one party benefiting at the expense of the other). Some argue that there can also exist commensal relationships between microbes and hosts, in which one party benefits and the other is unaffected. For example, most of our gut bacteria are usually classified as commensal.

3. By "misuse" I mean especially the use of antibiotics for infections they have no power to cure, and the failure to complete a full course of antibiotics once it is initiated.

4. R. Laxminarayan argues that whether antibiotics are best thought of as a renewable or exhaustible resource "depends on whether resistance declines when antibiotic use is withdrawn" (Laxminarayan, 2007, p. 19).

5. This is suggested by the steady decline in new antibiotics developed since the 1970s. One reason for this decline seems to be that scientists have already picked the low hanging fruit, such as antibiotics that are directly extracted from fungi, and new synthetic alternatives take longer to produce (Nathan, 2004). Another reason, suggested by a reviewer for this journal, may be that the market for new drugs is small because many of the victims of bacterial infections are people who cannot afford to pay for expensive new treatments.

6. Stiglitz (1999) points out that patents rarely promote basic science research because insights about the structure of the world are not usually patentable pieces of information.

7. Many non-biologists assume that biological evolution might be guided by some sort of divine plan. But microbiology is predicated on the assumption that forces, which drive evolutionary change, such as mutation, transposition and genetic drift, are deeply random. This makes the precise effects of an individual choice to consume antibiotics impossible to predict.

8. I am using "nation" to refer to the leaders of nations that are in a position to negotiate treaties, not as an anthropomorphic entity with its own intentions or desires.

9. Sinnott-Armstrong (2005) takes a similar position in his discussion about global warming.

10. Camerer (2003) finds that people tend to behave this way in public goods experiments with multiple rounds. These exhibit a similar structure to the kind of real world problem I am discussing.

11. http://www.nasa.gov/vision/earth/environment/ montreal_protocol.html.

12. It is likely, however, that if antimicrobial drugs were more expensive, firms would increase research into alternative ways of treating people with microbial infections. For example, some have proposed that since bacteria often coordinate their attack through chemical signals, we might be able to scramble the messages bacteria send to one another to prevent virulence. See Waters and Bassler (2005).

13. A global surveillance program would allow treaty participants to monitor patterns of use among their own citizens, and to identify those who harbor resistance genes but who cannot afford antibiotics. State agencies or non-governmental organizations would then be able to administer subsidized antibiotics to specific populations that put everyone at risk without encouraging overuse by indiscriminately lowering the price for everyone.

14. If some states are too poor to implement the treaty, we might be tempted to think that their citizens are also too poor to buy significant quantities of antibiotics, so that they do not pose a significant risk to other nations. But this is false, since many offpatent antibiotics are cheap, and many of the poorer nations are also those that permit over the counter sales of antibiotics. These people impose large risks on others, since they are most apt to misdiagnose themselves and to begin a course of antibiotics without finishing it.

\section{References}

Andersson, D. and Levin, B. (1999). The Biological Cost of Antibiotic Resistance. Current Opinion in Microbiology, 2, 489-493. 
Anomaly, J. (2009). Harm to Others: The Social Cost of Antibiotics in Agriculture. Journal of Agricultural and Environmental Ethics, 22, 423-435.

Barrett, S. (1999). Montreal vs. Kyoto. In Kaul, I., Grunberg, I. and Stern M. (eds.), Global Public Goods. New York, NY: Oxford University Press.

Barrett, S. (2007). Why Cooperate? The Incentive to Supply Global Public Goods. Oxford, UK: Oxford University Press.

Camerer, C. (2003). Behavioral Game Theory: Experiments in Strategic Interaction. Princeton, NJ: Princeton University Press.

Coase, R. (1960). The Problem of Social Cost. The Journal of Law and Economics, 3, 1-44.

Feinberg, J. (1987). Harm to Others: The Moral Limits of the Criminal Law. Oxford, UK: University Press: Oxford, UK.

Gaus, G. (1999). Social Philosophy. London, UK: M.E. Sharpe Publishing.

Kades, E. (2005). Preserving a Precious Resource: Rationalizing the Use of Antibiotics. Northwestern University Law Review, 99, 611-675.

Kaul, I., Grunberg, I. and Stern, M. (1999). Introduction. Global Public Goods. New York, NY: Oxford University Press.

LaFollette, H. (1980). Licensing Parents. Philosophy and Public Affairs, 9, 182-187.

Laxminarayan, R. (2003). On the Economics of Resistance. In Laxminarayan, R. (ed.), Battling Resistance to Antibiotics and Pesticides. Washington, DC: Resources for the Future.

Laxminarayan, R. (2007). Antibiotic Resistance: The Unfolding Crisis. In Laxminarayan, R. and Malani, A. (eds.), Extending the Cure. Washington, DC: Resources for the Future.

Levy, S. (1998). The Challenge of Antibiotic Resistance. Scientific American, 1998, 46-53. March.

Levy, S. (2002). The Antibiotic Paradox. Cambridge, MA: Perseus Publishing.

Gorbach, S. (2001). Antimicrobial Use in Animal FeedTime to stop. New England Journal of Medicine, 345, $169-178$.

Mill, J. S. (2002). On Liberty. New York, NY: The Modern Library.

Nathan, C. (2004). Antibiotics at the Crossroads. Nature, 431, 899-902.

Pigou, A. C. (1962). The Economics of Welfare. 4th ed. New York, NY: St. Martin's Press.
Rudholm, N. (2002). Economic Implications of Antibiotic Resistance in a Global Economy. Journal of Health Economics, 21, 1071-1083.

Sachs, J. S. (2007). Good Germs, Bad Germs: Health and Survival in a Bacterial World. New York, NY: Hill and Wang.

Sachs, J. S. (2008). DNA Pollution May Be Spawning Killer Microbes. Discover Magazine, 15 August 2009. http://discovermagazine.com/2008/mar/14-dnapollution-may-be-spawning-killer-microbes.

Salyers, A. and Amabile-Cuevas, C. (1997). Minireview: Why are Antibiotic Resistance Genes so Resistant to Elimination? Antimicrobial Agents and Chemotherapy, 41, 2321-2325.

Sandler, T. (1997). Global Challenges: An Approach to Environmental, Political, and Economic Problems. Cambridge, UK: Cambridge University Press.

Sandler, T. (2004). Global Collective Action. Cambridge, UK: Cambridge University Press.

Selgelid, M. J. (2007). Ethics and Drug Resistance. Bioethics, 19, 272-289.

Selgelid, M. J. (2009). A Moderate Pluralist Approach to Public Health Policy and Ethics. Public Health Ethics, 2, 195-205.

Sinnott-Armstrong, W. (2005). It's Not My Fault: Global Warming and Individual Obligations. In SinnottArmstrong, W. and Howarth, R. (eds.), Perspectives on Climate Change. Stamford, CT: JAI Press.

Smith, R. and Coast, J. (1997). Controlling Antimicrobial Resistance: a Proposed Transferable Permit Market System. Health Policy, 43, 219-232.

Smith, R. and Coast, J. (2004). Antimicrobial Drug Resistance. In Smith, R., Beaglehole, Ro, Woodward, D. and Drager, N. (eds.), Global Public Goods for Health. Oxford, UK: Oxford University Press.

Stiglitz, J. (1999). Knowledge as a Global Public Good. In Kaul, I., Grunberg, I. and Stern, M. (eds.), Global Public Goods. New York, NY: Oxford University Press.

Waters, C. and Bassler, B. (2005). Quorum Sensing: Cellto-Cell Communication in Bacteria. Annual Review of Cell and Developmental Biology, 21, 319-346.

WHO (2001a). Antibiotic Resistance: Synthesis of Recommendations by Expert Policy Groups. Geneva, Switzerland: WHO.

WHO (2001b). Global Strategy for Containment of Antimicrobial Resistance. Geneva, Switzerland: WHO. 